\section{Thyroid hormone profile in beta-thalassemia major children}

Thalassemia is the most common genetic disorder worldwide $^{1}$. The striking increase in survival of these patients over the past decade has focused attention on abnormal endocrine function, now the most prevalent iron-induced complication in older patients ${ }^{2}$. Trans-fusion related iron overload is the primary therapeutic complication in thalassemia major. Hemosiderosis of various endocrine glands including the thyroid gland has been documented histologically in chronically transfused patients including thalassemics. Iron deposition in various endocrinal glands is responsible for the hormonal derangements $\mathrm{s}^{3-6}$. Other factors like hypoxia due to persistent anemia and perfusion defect, also contribute to the derangement. Hypothalamicpituitary axis, thyroid, para-thyroid, adrenal, pancreas, gonads, all show hypoactivity. We therefore planned the present study with the aim to assess thyroid function in patients of $\beta$-thalassemia major and to evaluate its relation, if any, with serum ferritin levels.

The present study was conducted in our Thalassemia day care center. Thalassemia patients of 3-13 years age group, who were confirmed $\beta$ thalassemia cases and were on regular transfusion for more than 2 years were enrolled. Patients with any hormonal therapy or those terminally ill, were excluded. Fifty patients formed the study group and 50 age and sex matched patients of nonhematological and non-endocrinal, minor ailments admitted in general pediatric ward were taken as control. Both cases $(n=50)$ and controls $(n=50)$ were assessed for hemoglobin, serum triiodothyronine (T3), thyroxine (T4), thyroid stimulating hormone (TSH), transaminases, bilirubin and ferritin. On the basis of thyroid profile thalassemia patients were divided into euthyroid, compensated hypothyroid, uncompensated hypothyroid and overt hypothyroid. Their serum ferritin and thyroid profile were repeated after 1 year. Iron overload was also calculated as $133 \mathrm{mg}$ iron in each pack PCV transfused. Comparison was made between case and control for serum ferritin and thyroid profile. .

The mean age $( \pm \mathrm{SD})$ of thalassemia cases was 7.97 \pm 2.83 years (range $3-13$ years) and they received packed cell transfusions at an average interval of $16.12 \pm 2.6$ days. Out of 50 cases, 27 were on chelation therapy and 23 were on no chelation. Two cases were taking desferrioxamine infusion, 18 were on deferiprone and 7 cases were on combined chelation therapy.

Among cases the mean T3 $(139.38 \pm 25.55 \mathrm{ng} / \mathrm{dL})$ was comparable to that of controls $(135.5 \pm 35.12$ $\mathrm{ng} / \mathrm{dL})$. The mean $\mathrm{T} 4$ of cases $(7.36 \pm 1.61 \mu \mathrm{g} / \mathrm{dL})$ was significantly lower $(\mathrm{p}<0.001)$ than that of controls $(9.30 \pm 2.15 \mu \mathrm{g} / \mathrm{dL})$. The mean TSH level was significantly higher $(\mathrm{p}<0.01)$ in cases $(3.56 \pm$ $1.49 \mu \mathrm{g} / \mathrm{dL})$ as compared to controls $(2.31 \pm 2.74$ $\mu \mathrm{g} / \mathrm{dL})$.

Among thalassemia cases $70 \%$ were euthyroid $(\mathrm{n}=35), 18 \%$ were compensated hypothyroid $(\mathrm{n}=9)$, $12 \%$ were uncompensated hypothyroid $(\mathrm{n}=6)$ and none was overt hypothyroid or hyperthyroid. After 1 year we found no significant change in their proportions (Table I).

Table I: Thyroid function tests

\begin{tabular}{|c|c|c|c|c|}
\hline \multirow{2}{*}{$\begin{array}{l}\text { Thyroid } \\
\text { functions }\end{array}$} & \multicolumn{2}{|c|}{ Case $(n=50)$} & \multirow{2}{*}{$\begin{array}{l}\text { Control } \\
(n=50)\end{array}$} & \multirow{2}{*}{$\begin{array}{c}\mathrm{p} \\
\text { value }\end{array}$} \\
\hline & At start & After 1 year & & \\
\hline T3 (ng/dL) & $\begin{array}{l}139.38 \\
(25.55)\end{array}$ & $\begin{array}{l}133.46 \\
(33.66)\end{array}$ & $\begin{array}{c}135.5 \\
(35.12)\end{array}$ & $>0.05$ \\
\hline $\mathrm{T} 4(\mu \mathrm{g} / \mathrm{dL})$ & $\begin{array}{c}7.36 \\
(1.61)\end{array}$ & $\begin{array}{c}7.19 \\
(1.91)\end{array}$ & $\begin{array}{c}9.30 \\
(2.15)\end{array}$ & $<0.001$ \\
\hline $\mathrm{TSH}(\mu \mathrm{IU} / \mathrm{mL})$ & $\begin{array}{c}3.56 \\
(1.49)\end{array}$ & $\begin{array}{c}3.38 \\
(1.78)\end{array}$ & $\begin{array}{c}2.36 \\
(2.74)\end{array}$ & $<0.01$ \\
\hline
\end{tabular}

Data are mean (SD)

Table II: Comparison of transfusion parameter among hypothyroid and euthyroid patients

\begin{tabular}{l|ccc}
\hline & Hypothyroid patients $(\mathrm{n}=15)$ & Euthyroid patients $(\mathrm{n}=35)$ & $\mathrm{p}$ value \\
\hline Age at 1st $^{\text {transfusion (months) }}$ & $12.86 \pm 13.20$ & $13.2 \pm 14.61$ & $>0.05$ \\
Transfusion packs (in 1 year) & $21.86 \pm 5.63$ & $20.97 \pm 7.07$ & $>0.05$ \\
Iron overload (mg) & $2907.47 \pm 749.76$ & $2760.89 \pm 919.72$ & $>0.05$ \\
Frequency of transfusion days & $15.46 \pm 1.99$ & $16.12 \pm 2.60$ & $>0.05$ \\
Serum ferritin (at onset) & $3394.46 \pm 1169.11$ & $3195.68 \pm 1220.06$ & $>0.05$ \\
Serum ferritin (after 1 year) & $3549.60 \pm 1746.65$ & $3302.65 \pm 1417.18$ & $>0.05$ \\
SGOT (IU/L) & $75.66 \pm 45.03$ & $66.14 \pm 37.93$ & $>0.05$ \\
SGPT (IU/L) & $71.73 \pm 47.21$ & $81.45 \pm 60.98$ & $>0.05$ \\
Serum bilirubin (mg/dL) & $1.02 \pm 0.45$ & $1.23 \pm 0.83$ & $>0.05$ \\
\hline Data are mean (SD) & & &
\end{tabular}


While comparing the biochemical profile of euthyroid thalassemics $(\mathrm{n}=35)$ to hypothyroid thalassemics $(n=15)$ we found that the serum ferritin level of hypothyroid cases (3394.46 \pm $1169.11 \mathrm{ng} / \mathrm{L}$ ) was comparable to that of euthyroid cases $(3195.68 \pm 1220.06 \mathrm{ng} / \mathrm{L})$. Serum bilirubin, transaminases, hemoglobin and transfusion parameters were also comparable in these two groups (Table II).

We found no significant correlation between serum TSH level and iron overload, transfusion frequency, transaminases, serum bilirubin level among euthyroid and hypothyroid thalassemia patients.

Thyroid dysfunction has been variably reported in thalassemia patients ${ }^{7,8,9}$. Subclinical hypothyroiddism was observed in $30 \%$ of thalassemia patients in the index study. Although we found no case of clinical hypothyroidism in our study group, it was reported in $6.9 \%$ by Agrawal et $\mathrm{al}^{7}, 4 \%$ by Zerves et $\mathrm{al}^{10}, 18.3 \%$ by Morgo et $\mathrm{al}^{8}$, and in none, like in the index study ${ }^{9}$.

We found no correlation between thyroid dysfunction and age, amount of blood transfusion, liver dysfunction or degree of iron overload. Similar results have been documented ${ }^{11}$. Jain et al, observed that thyroid dysfunction was not related to age, sex, hemoglobin levels and country of origin, but transfused iron load (units/kg/year) was higher in patients with hypothyroid function, however, the difference was not statistically significant ${ }^{13}$. We found that thyroid dysfunction did not correlate with serum ferritin level. Similar observations have been made by others ${ }^{12,13,14}$.

We found no significant worsening in thyroid profile in thalassemia cases over the one year of study; however, Fisola et al, found that proportion of hypothyroidism increased from $8.4 \%$ to $13.9 \%$ over the period of 12 years in thalassemics ${ }^{14}$. The follow- up period of one year in the index study was possibly not long enough to pick up worsening thyroid status and a longer follow-up is recommended.

To conclude we documented hypothyroidism among a significant proportion of thalassemia patients. As pharmacological treatment for hypothyroidism is readily available, it is important to monitor thyroid function in these patients and institute prompt therapy when indicated.

\section{Geeta Gathwala, Kunal Das and Nitika Agrawal}

Department of Pediatrics, Pt. B.D. Sharma Postgraduate Institute of Medical Science, Rohtak, India. e-mail: drkunal80@ rediffmail.com

DOI: 10.3329/bmrcb.v35i2.2534

\section{References}

1. Rund D, Rachmilewitz E. Beta-thalassemia. New Engl J Med. 2005; 353: 1135-46.

2. Olivieri NF. The beta thalassemias. New Engl J Med. 1999; 341: 99-109.

3. Grundy RG, Woods KA, Savage MO, Evans JP. Relationship of endocrinopathy to iron chelation status in young patients with thalassemia major. Arch Dis Child. 1994; 71: 128-32.

4. Oerter KE, Kamp GA, Munson PJ, Nienhuis AW, Cassorla FG, Manasco PK. Multiple hormone deficiencies in children with hemochromatosis. J Clin Endocrinol Metab. 1993; 76: 357-61.

5. Oliver RAM. Siderosis following transfusion of blood. J Pathol Bacteriol. 1959; 77: 171-94.

6. Fucharoen S, Ketrichit P, Pootrakul P. Clinical manifestation of beta thalassemia/ hemoglobin E disease. J Pediatr Hematol Oncol. 2000; 22: 552-57.

7. Agarwal MB, Shah S, Vishwanatha C. Thyroid dysfunction in multitransfused iron loaded thalassemia patients. Indian Pediatr. 1992; 29: 997-1002.

8. Magro S, Puzzonia P, Consarino C, Galati MC, Morgione S, Porcelli D et al. Hypothyroidism in patients with thalassemia syndromes. Acta Haematol. 1990; 84: 72-76.

9. Phenekos C, Karamerou A, Pipis P, Constantoulakis M, Lasaridis J, Detsi S et al. Thyroid function in patients with homozygous $\beta$-thalassemia. Clin Endocrinol. 1984; 20: $445-50$

10. Zervas A, Katopodi A, Protonotarious A, Livadas S, Karagiorga M, Politis C et al. Assessment of thyroid function in two hundred patients with $\beta$-thalassemia major. Thyroid 2002; 12: 151-54.

11. Jain M, Sinha RSK, Chellani H, Anand NK. Assessment of thyroid function and its role in body growth in thalassemia major. Indian Paediatr. 1995; 32: 213-19.

12. Al-Hader A, Bashir N, Hasan Z, Khatib S. Thyroid function in children with $\beta$-thalassemia major in North Jordan. J Trop Paediatr. 1993; 39: 107-10.

13. Cavallo L, Licci D, Acquafredda A, Marranzini M, Beccasio R, Scardino ML et al. Endocrine involvement in children with $\beta$-thalassemia major: Transverse and longitudinal studies. Acta Endocrinol. 1984; 107: 49-53.

14. Filosa A, Di Maio S, Aloj G, Acampora C. Longitudinal study on thyroid function in patients with thalassemia major. J Paediatr Endocrinol Metab. 2006; 19: $1397-$ 404.

\section{Gastric symptoms and quality of life}

Gastrointestinal symptoms are common in the adult and elderly populations in North America, Europe, UK and Asia. The prevalence of upper gastrointestinal symptoms in Europe ranges from $25-35 \%$ and for the lower gastrointestinal symptoms from 3$22 \%$. It is estimated that up to $40 \%$ of adults in the U.K. suffer from gastrointestinal symptoms in any 